\title{
Adoption of Sinter Addition in Steelmaking Converter to Control Spitting
}

\author{
Sanjay Kumar Gupta, ${ }^{1}$ Abdhesh Prasad, ${ }^{1}$ Abhinandan Chatterjee, ${ }^{1}$ Manoranjan Kumar, \\ Somnath Ghosh, ${ }^{1}$ and Ramen Datta ${ }^{1}$ \\ ${ }^{1}$ R\&D Centre for Iron and Steel, Ranchi 834002, India \\ ${ }^{2}$ Steel Melting Shop-I, Rourkela Steel Plant, Rourkela 769011, India \\ Correspondence should be addressed to Sanjay Kumar Gupta; sanjayjsr@rediffmail.com
}

Received 30 June 2015; Revised 4 November 2015; Accepted 8 November 2015

Academic Editor: Sunghak Lee

Copyright (C) 2015 Sanjay Kumar Gupta et al. This is an open access article distributed under the Creative Commons Attribution License, which permits unrestricted use, distribution, and reproduction in any medium, provided the original work is properly cited.

Steel Melting Shop-I, Rourkela Steel Plant, Rourkela, produces 0.5 MT of various special steels through BOF-VAR/VOR-LF-CC route. One of the most serious problems in BOF operations was lance skulling, hood jamming, and build-up of metal in the mouth and cone of the furnace due to spitting and slopping. As spitting occurring during blowing increases, these particles of metal are deposited inside the mouth and cone and affect badly BOF productivity. In the present work, control of spitting has been established by addition of sinter during the period of spitting. It also helped to improve the slag formation and fluidity of slag through increase of $\mathrm{FeO}$ content during peak decarburisation period.

\section{Introduction}

The first-ever installed converters (65t) in India are at Steel Melting Shop-I, Rourkela Steel Plant, Rourkela, to produce $0.5 \mathrm{MT}$ of various special steels through Basic Oxygen Furnace- (BOF-) Vacuum Arc/Oxygen Degassing- (VAD/ VOD-) Ladle Furnace- (LF-) Continuous Casting (CC) route. The stringent quality requirements of special steel requires a high degree of precise control of operating parameters as well as immediate response to changes and interferences during production. Operating with small sized converter is always a challenge to achieve desired blowing parameters. One of the most serious problems in operations is the lance skull and the metal build-up in the mouth and cone of the furnace due to spitting and slopping. As spitting during blowing increases, these particles of metal are deposited further inside the mouth and cone.

The amount of iron droplets ejected in the BOF affects metallic yield, refectory wear, and the progress of decarburisation. Various studies [1-7] have been carried out to understand the phenomenon of spitting. Luomala et al. [1] have carried out the cold model studies to investigate the effect of lance height, lance nozzle angle, lance position, top gas flow rate, bottom blowing, and foamy slag on splashing and spitting. Kumar et al. [2] report the coolant strategies for BOF using different iron bearing material. Deo et al. [4] have mentioned the phenomenon of slag formation, foaminess, slopping in detail for various large and combined blowing converters. In this work, extensive trial was carried out to control the spitting by the addition of iron bearing material, that is, sinter, during the peak of dry slag formation. The control over slopping was achieved by improving the blowing parameters.

\section{Behaviour of a Top-Blown BOF Steel Making}

2.1. Outline. The main function of the $\mathrm{BOF}$ is to decarburise the hot metal using pure oxygen gas. In the top-blown BOF, pure oxygen is injected as a high-velocity jet against the surface of the hot metal, allowing penetration of the impinging jet to some depth into the metal bath. The pure oxygen topblown BOF can decarburise hot metal from 4.0\% C to $0.04 \%$ 


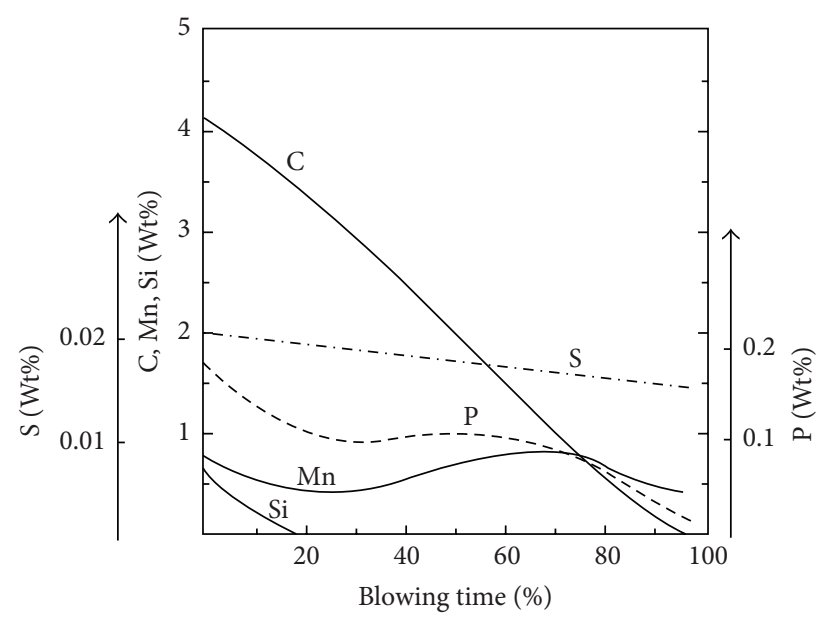

FIgURE 1: Evolution of bath composition with blowing time.

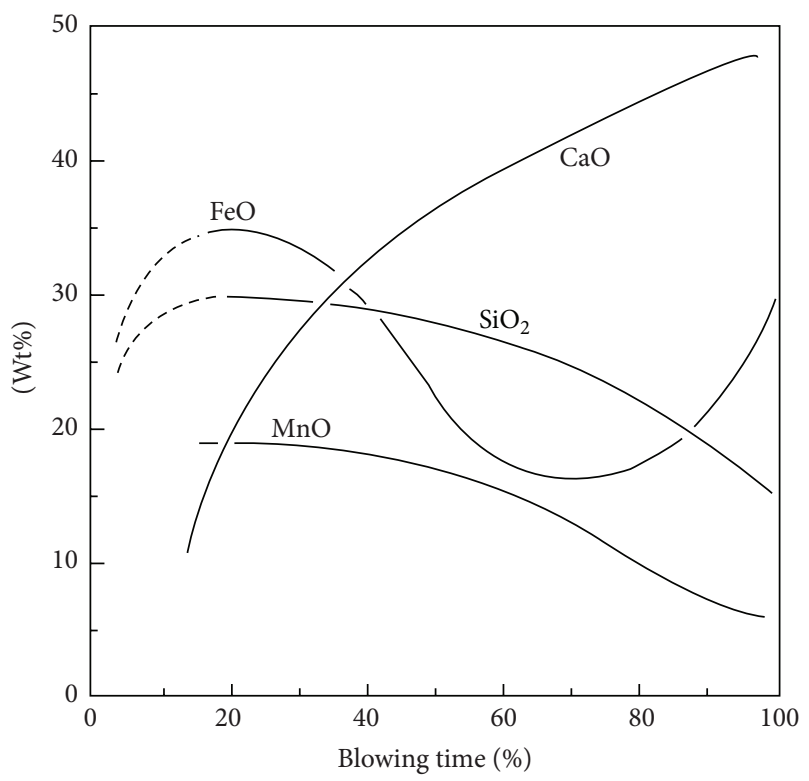

FIGURE 2: Evolution of slag composition with blowing time.

carbon. Under these conditions, the elements like Fe, Si, Mn, and $\mathrm{P}$ are oxidised to form the slag. Silicon oxidisation is completed in early period of blow, whereas carbon removal takes place during the entire period of blow. The evaluation of bath composition [7] is shown in Figure 1. Different basic fluxes like calcined lime and calcined dolomite are added to make a basic slag during the blow for refining of steel and protection of vessel refractory. Figure 2 shows the evaluation of slag composition [7] for BOF converter. As the blow progresses, lime $(\mathrm{CaO})$ steadily dissolves in the slag and slag weight [7] increases (Figure 3). The oxygen reacts directly with carbon in the hot metal to produce $\mathrm{CO}$ and $\mathrm{CO}_{2}$ and escapes in the waste gas. Small amount of iron (oxidised or vaporised in the jet impact region) also escapes as oxide fume. In addition to vaporisation/oxidation of iron, metal and slag droplets are produced due to impact of the jet on metal bath (hot spot). Very fine metal and slag droplets can be carried away directly from hot spot along with the waste gases. Under



FIGURE 3: Increasing mass of slag with oxygen blown.

certain conditions, the slag droplet mixture (usually iron rich) is deposited on the mouth of converter and on the lance. When the deposit on lance becomes excessive, then lance skull has to be removed or the lance is replaced by a new one. The skull formed on converter mouth due to deposition of slag and metal is also undesirable and is cleaned from time to time.

2.2. BOF Oxygen Blowing and Lance Height. After scrap and hot metal are charged, oxygen is supplied through a water cooled lance continuously at different lance height above steel bath. The blowing rates and lance height vary considerably from shop to shop and depend on the pressure and quality of the oxygen supply. A practical limit on the rate is often the volume of the furnace and the capacity of the gas collection and cleaning system to handle the gaseous reaction product and fume.

At the start of blow, lance height is kept at higher level to avoid the possibility of lance tip contact with the scrap and to safely establish the oxidising condition and heat generating reactions. The purpose here is to increase the reaction rate and control the early slag formation by generating early iron oxide.

Most of the reactions occur during the mid blowing period which is the longest duration. The lance height is an empirical compromise between achieving faster carbon removal rates and proper slag making. At the end of the blow, lance height is kept slightly higher to control the viscosity and chemical reactivity of the slag by raising its $\mathrm{FeO}$ content.

\section{Experimental}

During oxygen blowing excessive ejection of the metal droplet (spitting) and sticking to the converter hood was a perennial problem. The frequent hood jamming and lance jamming need frequent shut downs for their clearing and, therefore, it is affecting the shop productivity. In view of this, 
the following modifications were initiated for improving the BOF blowing parameters.

(i) Fluid and early slag formation: in the earlier blowing practice, the operating basicity $\left(\mathrm{CaO} / \mathrm{SiO}_{2}\right) \sim 4.0$ was kept at higher side. This led to delayed dissolution of fluxes and viscous/dry slag formation and hence caused excessive spitting. The material charge balance was modified to optimise the operating basicity in the range of 3.0-3.2. Higher hot metal temperature, small size/light scrap, and retaining slag practice were recommended for early slag formation.

(ii) Addition of sinter: the addition of sinter was done in 2-4 batches of $50-100 \mathrm{~kg}$ during decarburisation period (7-16 min) or/and excessive spitting condition. The typical composition of sinter was $\mathrm{Fe}$ (total)$55 \%, \mathrm{CaO}-10 \%, \mathrm{SiO}_{2}-5 \%, \mathrm{Al}_{2} \mathrm{O}_{3}-2.5 \%, \mathrm{MgO}-6 \%$. For achieving the desired tapping condition, the heat balance was considered by reducing the scrap charge based on the opening temperature of the previous heat.

(iii) Adjustment of lance height during spitting: during severe spitting condition, the increase in lance height for short period was done for extra oxidation of iron.

(iv) In case of heavy bottom build-up, reduced bottom flux addition by $50 \%$ was recommended and balance additions of fluxes were adjusted during the blow.

(v) Optimum lance height during oxygen blowing is essential to control the spitting. To ensure the correctness of lance height, regular lance height measurement for correction of bottom build-up or BOF bottom erosion was recommended.

\section{Result and Discussion}

The most important reaction in steelmaking is decarburisation. It determines not only the process time but also the $\mathrm{FeO}$ content of the slag, affecting yield and refining. When oxygen is injected into an oxygen steelmaking furnace, a tremendous quantity of gas is evolved, forming a gas-metal-slag emulsion. The chemical reactions take place between the metal droplets, the slag, and gas in the emulsion. These reactions take place in the gas phase (primarily $\mathrm{CO}$ ) that separates the slag and metal and play important role in decarburisation.

The metal droplets are generated as a result of oxygen jet impact and the shearing action of the gas flow from the impact region where the jet strikes the metal surface and the gases are deflected upwards. Molloy [8] described the jet-liquid interaction in terms of three modes: dimpling, splashing, and penetrating. The $\mathrm{CO} / \mathrm{CO}_{2}$ gases are formed as a result of the oxidation of carbon mainly in the jet impact zone and at the droplet-slag and slag-metal interfaces. As the reduction of $\mathrm{FeO}$ in the slag takes place, the generation of $\mathrm{CO} / \mathrm{CO}_{2}$ gas raises the foam height. The foam formed is usually a heterogeneous mixture of droplets, gas bubbles, undissolved flux particles (of lime, dolomite, and iron ore), and liquid slag. The intensity of foaming in top-blown converters is sometimes so high that the foam comes out through the mouth of the converters. This phenomenon is technically termed "slopping." The control of foaming and slopping is necessary for a steady operation.

The foaming steadily increases after $25 \%$ of the blowing time and attains a maximum value around the middle of the blow. The foam begins to die after $75 \%$ of the blowing time; during $25-75 \%$ of the blowing time, the basicity of the slag steadily increases from 1.2 to approximately 2.0 while the $\mathrm{FeO}$ content of the slag is at lower level.

Lance height has a great effect on foaming because it affects the rate of generation of metal droplets as well as the recirculation of slag and gas within the vessel. Lance height adjustment can be used as a tool to control the foaming of slag; if lance height is decreased, then foaming decreases and therefore, during slopping, lance is lowered.

For the reduction of $\mathrm{FeO}$ in slag to continue, it is essential that the slag remains in fluid state because the reduction kinetics of $\mathrm{FeO}$ in the slag is controlled by mass transport of $\mathrm{FeO}$ in the slag. Due to reduction of $\mathrm{FeO}$, the melting point of the slag increases and it may become viscous. Another main reason for the increase in the viscosity of slag could be the precipitation of dicalcium silicate due to reaction of lime with silica in the slag. It can be seen that a delicate balance of the reduction of FeO in slag and slag viscosity is needed. For example, if more $\mathrm{FeO}$ is reduced and is not adequately compensated with $\mathrm{FeO}$ received from the jet impact zone (via the oxide formed on the surface of metal droplets), then the conditions for foaming do not remain favourable, and slag becomes viscous. Once the reduction of FeO stops (or slows down) due to increase in slag viscosity, oxygen begins to accumulate in the slag. During this temporary period of viscous or dry slag formation, "spitting" phenomenon (ejection of liquid metal droplets due to jet impact, even reaching up to the mouth of converter) is observed. Prolonged spitting can cause skulling of lance, burning of lance tip, and deposition of slag-droplet mixture at the mouth of and inside the converter hood.

With the progress of the blow, at a later stage, when the slag melts due to rise in the temperature of the system, the carbon of the droplets then reduces the $\mathrm{FeO}$ and a great surge in the reduction rate of $\mathrm{FeO}$ may again result in slopping. This is why a brief dry slag period is often accompanied by slopping at around $75-90 \%$ of the blow.

The position of the lance is very important for proper functioning of the process. If the lance is too high, the slag will be overstirred and overoxidised with higher $\mathrm{FeO}$ percentages. This will cause higher than normal yield losses and lower ferroalloy efficiencies due to oxidation losses. Further, the rate of carbon removal is reduced and becomes erratic. Slag volume increases and there is an increased chance of slopping, in which an uncontrolled slag is spilling over the top of the furnace. If lance height is kept at lower side, carbon removal increases somewhat and slag formation, slag reactivity, and $\mathrm{FeO}$ are reduced and can cause poor phosphorus removal. Simultaneously, at lower lance height, excessive spitting of metal droplet causes severe metallic deposits on lance. Therefore, there should be an optimum lance height profile depending upon the furnace configuration, lance configuration, and oxygen supply pressure or flow rate. 
TABLE 1: Comparison of BOF operating data.

\begin{tabular}{|c|c|c|}
\hline BOF operating parameters & Without sinter addition & With sinter addition \\
\hline Hot metal charge, $\mathrm{kg} /$ ton of crude steel (tcs) & 1076.9 & 1090.8 \\
\hline Scrap charge, $\mathrm{kg} / \mathrm{tcs}$ & 110.8 & 88.5 \\
\hline Cal. lime, $\mathrm{kg} / \mathrm{tcs}$ & 63.7 & 64.5 \\
\hline Cal. dolo., kg/tcs & 15.4 & 13.7 \\
\hline Oxygen consumption, $\mathrm{Nm}^{3} / \mathrm{tcs}$ & $53.3(49.2-55.4)$ & $55.0(49.2-61.5)$ \\
\hline Opening temp., ${ }^{\circ} \mathrm{C}$ & $1626(1601-1655)$ & $1621(1600-1681)$ \\
\hline \multicolumn{3}{|c|}{ Converter steel analysis } \\
\hline C, $\%$ & $0.04(0.03-0.07)$ & $0.04(0.03-0.07)$ \\
\hline $\mathrm{Mn}, \%$ & $0.021(0.02-0.03)$ & $0.02(0.01-0.03)$ \\
\hline $\mathrm{P}, \%$ & $0.02(0.014-0.028)$ & $0.019(0.012-0.032)$ \\
\hline S, \% & $0.057(0.044-0.08)$ & $0.053(0.042-0.076)$ \\
\hline \multicolumn{3}{|c|}{ Slag composition } \\
\hline $\mathrm{FeO}, \%$ & $28.6(27.5-29.3)$ & $27.01(25.6-29.33)$ \\
\hline $\mathrm{SiO}_{2}, \%$ & $10.31(9.86-10.6)$ & $10.28(9.58-11.62)$ \\
\hline $\mathrm{CaO}, \%$ & $46.76(44.34-48.5)$ & $47.02(45.6-48.76)$ \\
\hline $\mathrm{MgO}, \%$ & $3.91(2.51-5.71)$ & $3.62(2.33-4.2)$ \\
\hline $\mathrm{Al}_{2} \mathrm{O}_{3}, \%$ & $0.7(0.4-1.1)$ & $0.49(0.35-0.62)$ \\
\hline $\mathrm{TiO}_{2}, \%$ & $0.69(0.56-0.85)$ & $0.77(0.6-0.9)$ \\
\hline $\mathrm{P}_{2} \mathrm{O}_{5}, \%$ & $2.41(2.13-2.6)$ & $2.38(2-2.48)$ \\
\hline S, \% & $0.17(0.11-0.23)$ & $0.17(0.15-0.18)$ \\
\hline
\end{tabular}

For achieving improved slag formation and to control spitting, the addition of sinter during blowing was optimised by extensive trial. The BOF operating data was collected and compared with the heats where no sinter was added (as tabulated in Table 1). The comparison of BOF operating data for both categories was analysed to understand the effect of sinter addition on control of spitting and hood jamming. The observed BOF parameters were found similar. The first turndown temperature was slightly lowered by $5^{\circ} \mathrm{C}\left(1621^{\circ} \mathrm{C}\right.$ as compared to $1626^{\circ} \mathrm{C}$ ) when sinter was added. Improved blowing was observed with respect to control over spitting, lance jamming, and hood jamming. The addition of sinter during peak decarburisation period was found to be an effective method to control spitting.

Sinter has chemical characteristics similar to the lump iron ore. However, sinter being in a reduced condition and prefluxing have slightly different effect compared with ore. The iron oxide and flux in the sinter help in early formation of more effective slag and chilling of bath is relatively less effective compared to iron ore. It has been noticed that the sinter has more foaming tendency than the lump ore, which results in increased slopping if added in higher quantity. Sinter was found to be a good replacement of iron ore when lump ore gets wet and hence becomes difficult to handle in BOF batching systems.

Sinter can be charged into the BOF for improving the slag condition to improve its fluidity by increasing the $\mathrm{FeO}$ content in the slag. The cooling efficiency is about three times higher energy than required to melt same quantity of scrap. During spitting, addition of sinter provides the sufficient $\mathrm{FeO}$ in the slag to increase in fluidity which controls

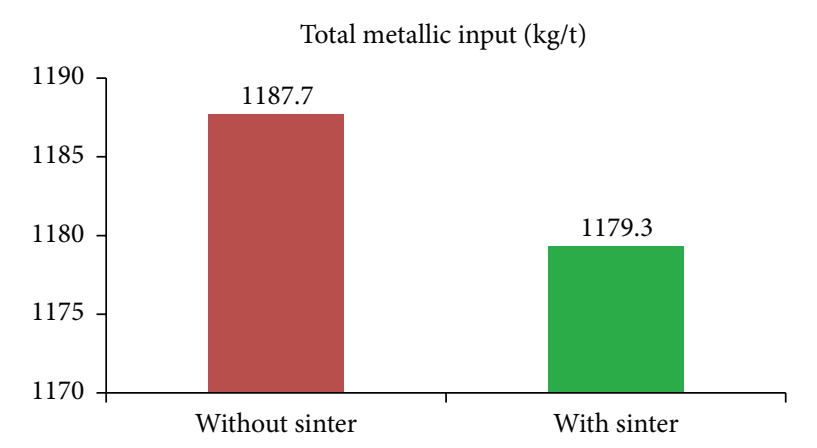

FIgURE 4: Comparison of total metallic inputs for trial heats with sinter addition.

spitting. The challenges remain during higher usage of higher quantity of sinter to control the excessive slag foaming. Added sinter $(\mathrm{FeO})$ undergoes reduction and releases iron and oxygen. This additional oxygen becomes available for carbon removal, thus speeding up the overall reaction. Slopping is likely caused by the increased slag volume and the increased reaction rate. It is obvious that blowing pattern is the key controlling parameter for sinter addition and, hence, hard blowing configurations are essential to minimize the foaming tendency. Additions in small batches of 2-3 nos in an interval of $\sim 2$ min provide precise control over the temperature and slag volume. Reduction in total metallic input $\sim 8 \mathrm{~kg} / \mathrm{t}$ has been observed due to recovery of $\sim 75 \%$ of the iron in the sinter; the remainder contributes to the iron oxide in the slag. This helps in increasing the FeO percentage in slag and makes it foamy (Figure 4). 


\section{Conclusion}

One of the most serious problems in BOF operations is the lance skull and the build-up of metal in the mouth and cone of the furnace due to spitting and slopping. Control of spitting was carried out by addition of sinter during the period of spitting. The first turndown temperature was found slightly in lower side due to higher cooling efficiency of sinter. During blowing, addition of sinter provides the sufficient $\mathrm{FeO}$ in the slag to increase in fluidity and to control the spitting. The biggest challenge with high sinter usage was to control the excessive slag foaming. Slopping is likely caused by the increased slag volume and by the increased reaction rate. It is obvious that blowing pattern is the key controlling parameter for sinter addition and hence hard blowing configurations are required to minimize the foaming tendency. Additions in small batches of 2-3 nos in an interval of 2 min provide precise control over the temperature and slag volume. Improved blowing was observed during trial with respect to control of spitting, lance, and hood jamming. The addition of sinter during decarburisation period was found to be an effective method to control spitting.

\section{Conflict of Interests}

The authors declare that there is no conflict of interests regarding the publication of this paper.

\section{Acknowledgments}

The authors are thankful to management of RSP for providing an opportunity for conducting trials. The authors are grateful to the management of RDCIS for their permission to publish this paper.

\section{References}

[1] M. J. Luomala, T. M. J. Fabritius, E. O. Virtanen, T. P. Siivola, and J. J. Harkki, "Splashing and spitting behaviour in the combined blown steelmaking converter," ISIJ International, vol. 42, no. 9, pp. 944-949, 2002.

[2] D. S. Kumar, G. Prasad, P. K. Ghouri, and M. Ranjan, "Coolant strategies for BOF steelmaking," Iron Making \& Steel Making, vol. 35, no. 7, pp. 539-544, 2008.

[3] R. D. Phelke, BOF Steelmaking, vol. 2, chapter 12, ISS, Warrendale, Pa, USA, 1975.

[4] B. Deo, A. Overbosch, B. Snoeijer, D. Das, and K. Srinivas, "Control of slag formation, foaming, slopping, and chaos in BOF," Transactions of the Indian Institute of Metals, vol. 66, no. 5-6, pp. 543-554, 2013.

[5] Y. Higuchi and Y. Tago, "Effect of lance design on jet behavior and spitting rate in top blown process," ISIJ International, vol. 41, no. 12, pp. 1454-1459, 2001.

[6] K.-I. Naito, N. Asahara, A. Kaizawa et al., "Nippon steel plant report (internal report)," Nippon Steel Technical Report 104, 2013.

[7] B. Deo and R. Boom, Fundamentals of Steelmaking Metallurgy, Prentice Hall International (UK) Limited, 1993.

[8] N. A. Molloy, The Journal of the Iron and Steel Institute, pp. 943950, 1970. 

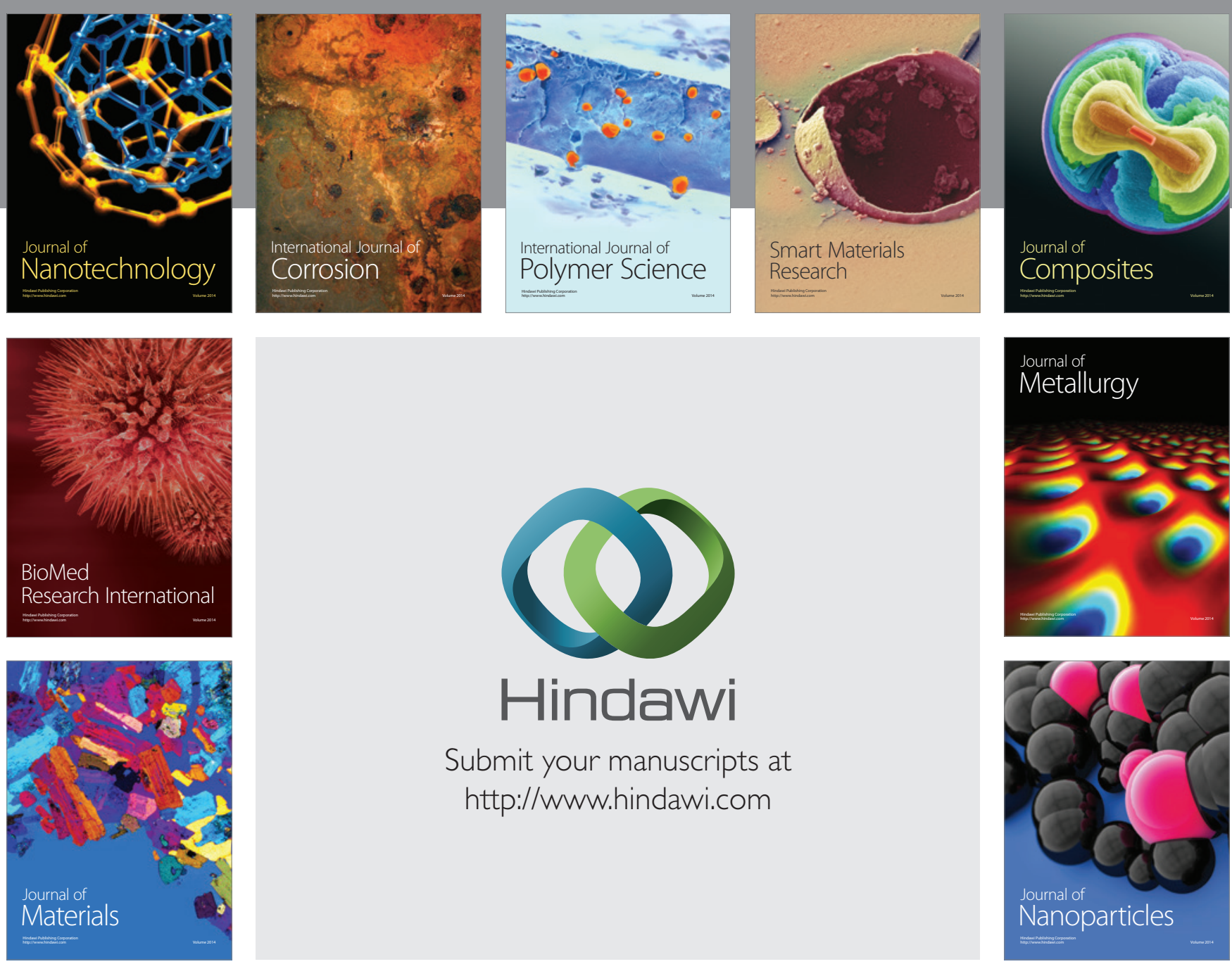

Submit your manuscripts at http://www.hindawi.com
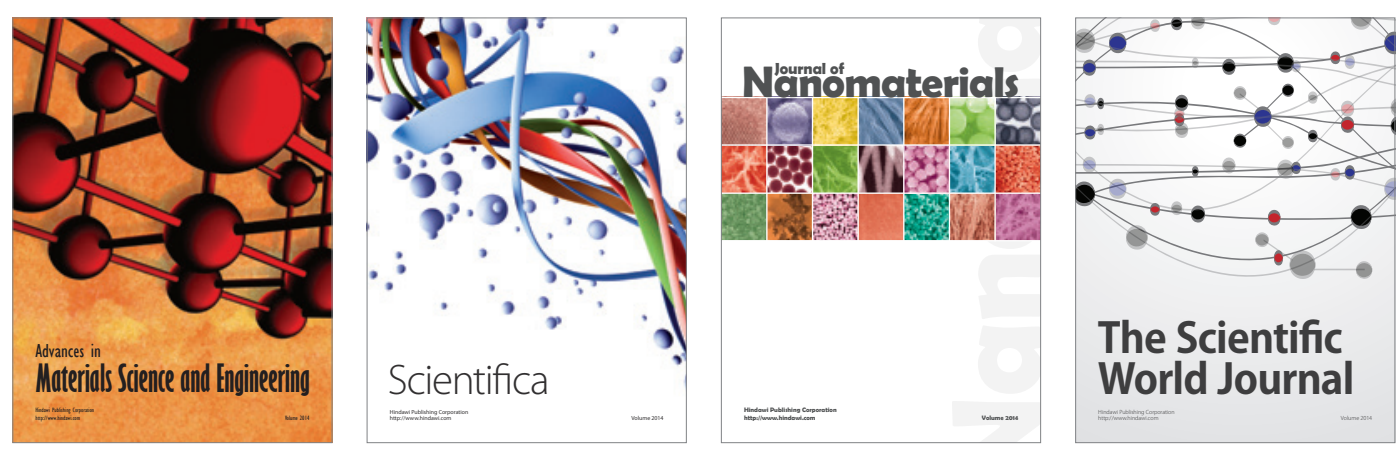

\section{The Scientific World Journal}
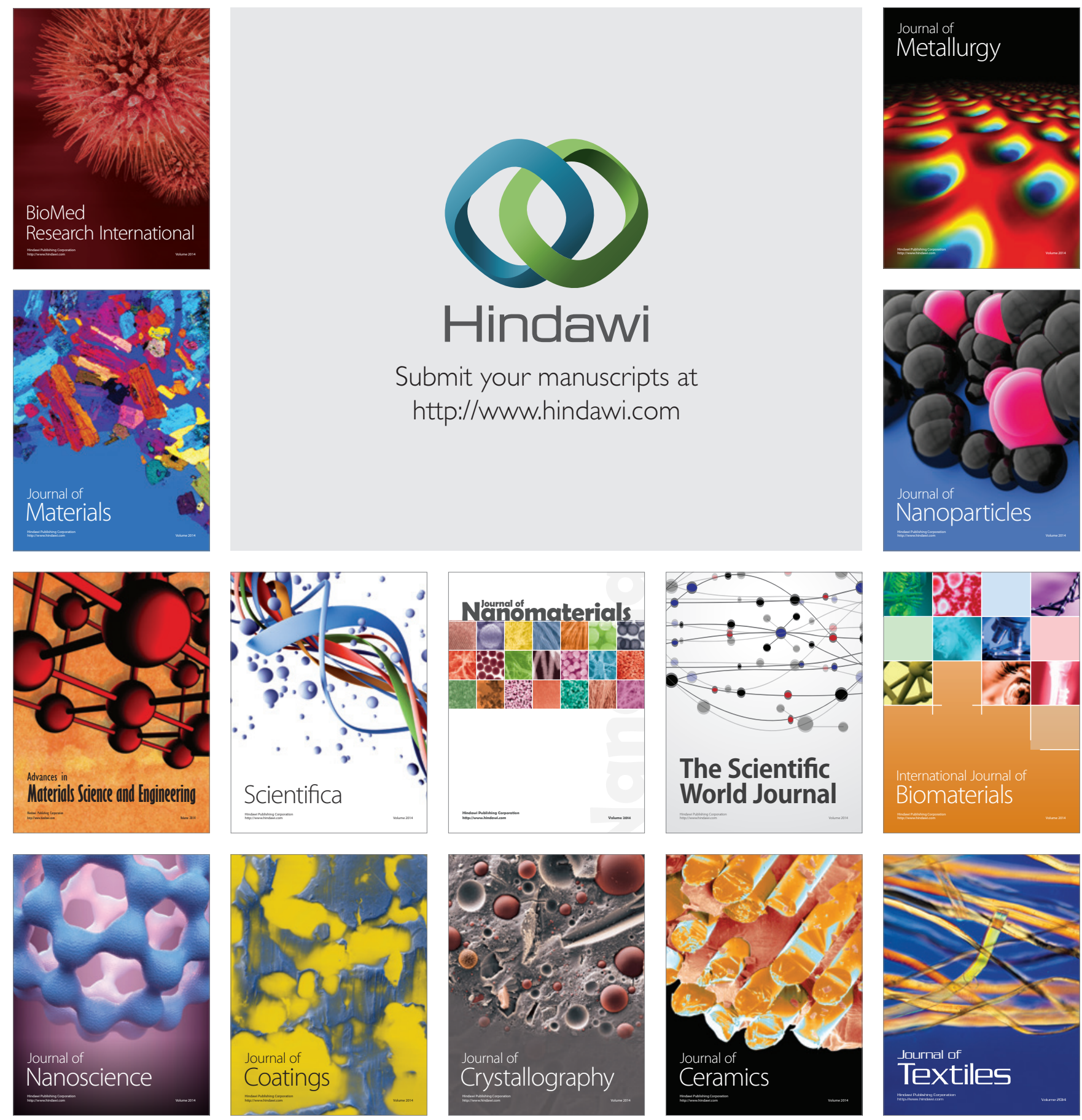